\title{
Seasonal variability in stable isotopes of estuarine consumers under different freshwater flow regimes
}

\author{
Jill A. Olin ${ }^{1,4, *}$, Nigel E. Hussey ${ }^{1}$, Scott A. Rush ${ }^{1,5}$, Gregg R. Poulakis ${ }^{2}$, \\ Colin A. Simpfendorfer ${ }^{3}$, Michelle R. Heupel ${ }^{3}$, Aaron T. Fisk ${ }^{1}$ \\ ${ }^{1}$ Great Lakes Institute for Environmental Research, University of Windsor, Windsor, Ontario N9B 3P4, Canada \\ ${ }^{2}$ Florida Fish and Wildlife Conservation Commission, Fish and Wildlife Research Institute, \\ Charlotte Harbor Field Laboratory, Port Charlotte, Florida 33954-1006, USA \\ ${ }^{3}$ School of Earth and Environmental Sciences, James Cook University, Townsville, Queensland 4811, Australia \\ ${ }^{4}$ Present address: Department of Oceanography and Coastal Sciences, Louisiana State University, Baton Rouge, \\ Louisiana 70803, USA \\ ${ }^{5}$ Present address: College of Forest Resources, Forest and Wildlife Research Center, Box 9680, Mississippi 39762-9690, USA
}

\begin{abstract}
Freshwater inflow from riverine sources is essential for estuarine productivity. However, human alterations to freshwater flow have resulted in modifications to the seasonal complexities of estuarine communities. To quantify changes in energy transfer at the trophic guild and consumer levels that result from anthropogenic-altered flow, we evaluated seasonal trends over a $1 \mathrm{yr}$ period in stable isotopes of carbon $\left(\delta^{13} \mathrm{C}\right)$, nitrogen $\left(\delta^{15} \mathrm{~N}\right)$ and sulfur $\left(\delta^{34} \mathrm{~S}\right)$ in nekton species sampled from 2 subtropical tidal rivers, one that is relatively natural and one that experiences regulated flow discharges that result in autumnal high-flow events. Primary and secondary consumers in the flow-altered estuary exhibited a significant depletion in ${ }^{13} \mathrm{C}$ and enrichment in ${ }^{15} \mathrm{~N}$ $(\sim 2 \%$ in both isotopes respectively) with the onset of the wet season, while the stable isotope values of high trophic level species (i.e. $\geq$ tertiary consumers) remained relatively consistent, trends were not apparent in the natural estuary. These isotopic trends were evident in both benthic and pelagic consumers, suggesting a food web-wide influence of altered flow on nutrient dynamics. Although the relative trophic structure, based on $\delta^{15} \mathrm{~N}$, was consistent across seasons and among estuaries, the $\delta^{34} \mathrm{~S}$ values were less seasonally variable in the flow-altered estuary and were indicative of more terrestrial/freshwater-influenced values compared to the natural estuary, suggesting a lengthened influence of high flow. Although limited in temporal scope, our results indicate a noteworthy difference in seasonal isotope dynamics of lower trophic level consumers in a flow-altered estuarine food web. The importance of this effect on ecosystem function warrants further attention.
\end{abstract}

KEY WORDS: Disturbance $\cdot$ Benthic $\cdot$ Pelagic $\cdot$ Resource use $\cdot$ Stable isotopes $\cdot$ Trophic guilds

\section{INTRODUCTION}

Hydrological connectivity, or the water-mediated transfer of matter, energy and/or organisms within or between elements of the hydrological cycle, is considered to be the most influential factor driving aquatic ecosystem dynamics (Pringle 2001). Anthropogenic alterations to this connectivity, in the form of dams and diversions, have resulted in habitat fragmentation and degradation as well as modifications to river flow (Nilsson et al. 2005, Lotze et al. 2006). Modifications to river flow, primarily driven by appropriation 
of freshwater for human use, is considered the most pervasive and deleterious effect on rivers (Kingsford 2011). As few estuarine systems worldwide remain unaffected by upstream manipulation of their freshwater inflow (Dynesius \& Nilsson 1994), these modifications to rivers can have major implications for individual species and thus the structure of downstream estuarine and coastal marine communities (Edeline et al. 2005, Serrano et al. 2010).

The contribution of freshwater to downstream habitats is regarded as a critical landscape process in riverine systems (Sklar \& Browder 1998), regulating the physical, chemical and biological properties of terrestrial, lacustrine, and marine environments (Paerl et al. 2010, Rush et al. 2010). Within estuaries, freshwater inflow from riverine sources seasonally provides nutrients, sediment and organic matter essential for primary and secondary production (Mallin et al. 1993, Drinkwater \& Frank 1994, Chanton \& Lewis 2002). Life history strategies (e.g. breeding, spawning and recruitment) of estuarine species are commonly synchronized with particular flow patterns (Bunn \& Arthington 2002, Rehage \& Trexler 2006) and variable salinity tolerances can produce communities segregated along salinity gradients (Rakocinski et al. 1992, Gelwick et al. 2001, Montagna et al. 2002, Akin et al. 2003).

Alterations to hydrology are known to result in community changes to estuarine systems, such as the composition and abundances of nekton species (e.g. Greenwood et al. 2006, 2007, Baptista et al. 2010). However, it is less well known how these alterations lead to changes in nutrient and energy transfers through estuarine communities. Response to altered flow patterns is, however, anticipated to be most evident among lower trophic level species (i.e. primary and secondary consumers). This prediction is based on primary and secondary consumers having limited mobility yet which are capable of assimilating variable mixtures of locally-based organic matter sources (Deegan \& Garritt 1997, Wainright et al. 2000, Hsieh et al. 2002) that often coincide with changes in physiochemical processes (McLeod \& Wing 2008). This has broad implications for individual species and the overall stability of the entire community.

Here we examined the seasonal variability (i.e. transition from dry to wet season) over one annual cycle in the flow of energy to nekton consumers in the Charlotte Harbor Estuary, southwest Florida. We compared trends in stable isotopes of carbon $\left(\delta^{13} \mathrm{C}\right)$, nitrogen $\left(\delta^{15} \mathrm{~N}\right)$ and sulfur $\left(\delta^{34} \mathrm{~S}\right)$ between estuaries of 2 tidal rivers; one that has undergone major human development and experiences an altered-flow re- gime, and one that is relatively natural. Shifts in isotopic values of estuarine species have been observed to occur with high flows, particularly those associated with heavy rains and monsoons (Wai et al. 2008, Abrantes \& Sheaves 2010). In both river systems, a significant proportion of annual riverine flow $(\sim 60 \%)$ is concentrated in the wet season (i.e. June to September), typical of the majority of rivers in southwest Florida (Kelly \& Gore 2008). A fundamental premise of our analysis, however, was that the wet season in the modified river is exaggerated by anthropogenicaltered flow when compared to the natural system. Our objectives were to (1) compare the seasonal change in estuarine nekton trophic relationships and (2) compare the relative nutrient sources of consumer species and trophic guilds, sampled from a flowaltered and a more natural system. We expected that species sampled following the dry season would be enriched in ${ }^{13} \mathrm{C}$ and ${ }^{34} \mathrm{~S}$ relative to those sampled following the wet season, reflecting a polyhaline estuarine status (i.e. tidally influenced) in both estuaries. In contrast, with the exaggerated wet season in the altered system, consumers were expected to exhibit significantly depleted ${ }^{13} \mathrm{C}$ and ${ }^{34} \mathrm{~S}$ values, reflective of an oligohaline estuarine status (i.e. terrestrial/freshwater influenced; Chanton \& Lewis 2002, Atwood et al. 2012).

\section{MATERIALS AND METHODS}

\section{Study sites}

The Caloosahatchee River, located on the southwest coast of Florida ( $26^{\circ} 30^{\prime} \mathrm{N}, 81^{\circ} 54^{\prime} \mathrm{W}$ ), is a major tributary of Charlotte Harbor, Florida, USA (Fig. 1). The Caloosahatchee River watershed drains an area of approximately $4550 \mathrm{~km}^{2}$. Prior to the artificial connection to Lake Okeechobee, the Caloosahatchee River was a smaller, meandering river originating at the west end of Lake Flirt and extending to Beautiful Island in Ft. Myers (Flaig \& Capece 1998). Intensive agriculture became the major land use in the watershed with the construction of extensive drainage projects in the 1880 s; additional channelization and dam construction have occurred at Moore Haven, Ortona and Franklin Lock and Dam (Flaig \& Capece 1998). The Caloosahatchee River currently extends about $68 \mathrm{~km}$ from Lake Okeechobee to Franklin Lock. This final downstream structure defines the beginning of the Caloosahatchee Estuary and extends for approximately $42 \mathrm{~km}$ to San Carlos Bay. These modifications to the 


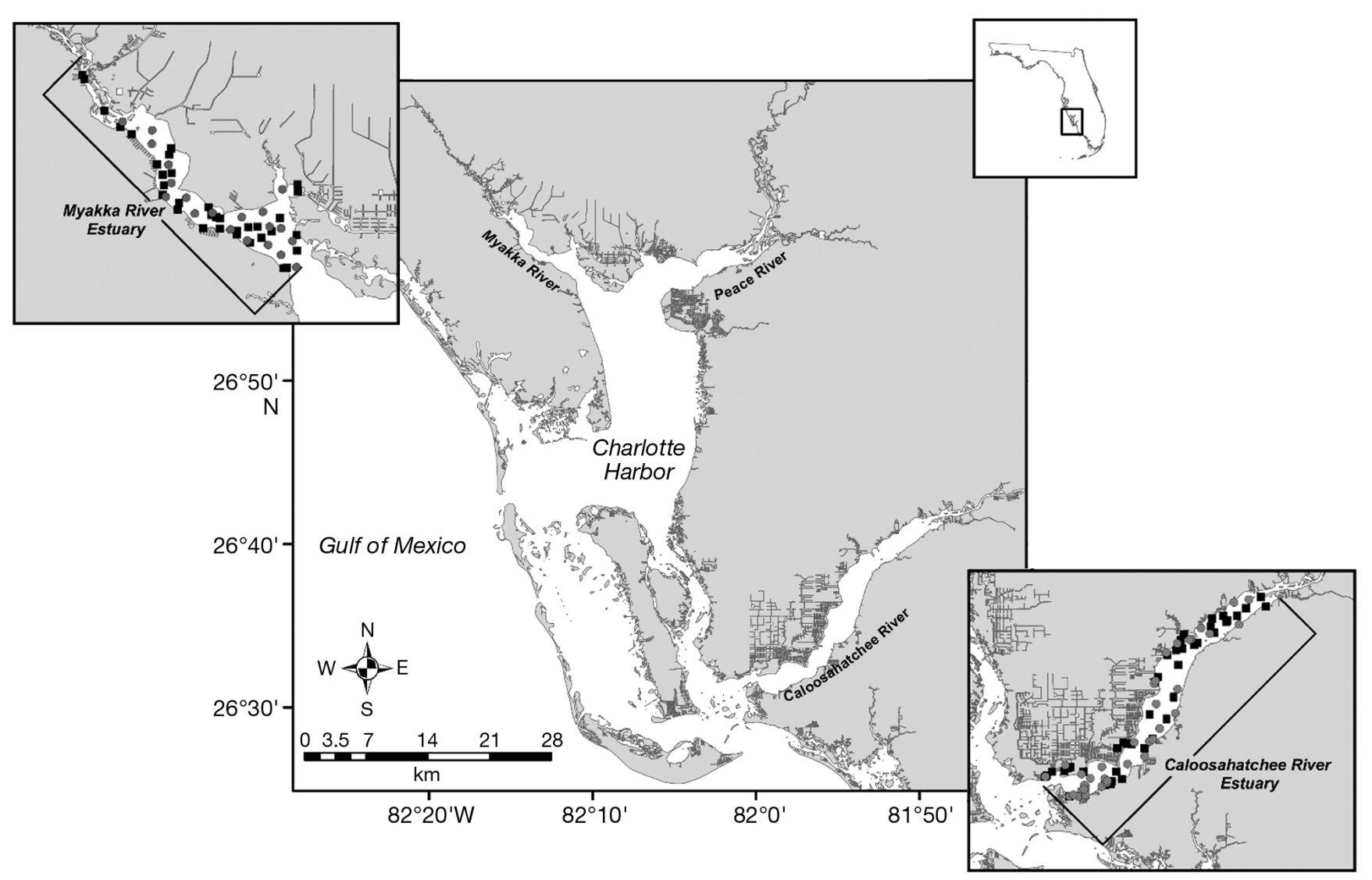

Fig. 1. Study area showing locations of the Caloosahatchee and Myakka Rivers on the southwestern coast of Florida. Insets show sampling locations (water quality and consumer species; : spring, $\mathbf{\square}$ : autumn) within the estuarine portion of the rivers

hydrology of the Caloosahatchee River in combination with land-use development (e.g. Ft. Myers) have resulted in large-scale alterations in the estuary. The salinity gradient of the Caloosahatchee estuary cycles annually; during the winter and spring months (dry season) the estuary ranges from mesohaline (salinity ranging from 5 to $18 \%$ ) to polyhaline (salinity range of 18 to $30 \%$ ), while during the summer and autumn months (wet season) the estuary can become exclusively oligohaline (salinity range 0 to $5 \%$ ), with minimal tidal influence (Doering \& Chamberlain 1998, Flaig \& Capece 1998). This distinct transition between dry and wet seasons largely results from high anthropogenic discharge (Fig. 2) and can be rapid, often occurring in less than a week. After discharge decreases, the river returns to a mesohaline gradient.

The Myakka River $\left(82^{\circ} 12^{\prime} \mathrm{W}, 26^{\circ} 57^{\prime} \mathrm{N}\right)$, draining into the northern portion of Charlotte Harbor, was selected as a control site for comparison with the Caloosahatchee River (Fig. 1). The Myakka River was chosen for several reasons: (1) it is proximately located $(<100 \mathrm{~km})$ to the Caloosahatchee River, and is characterized by a similar species assemblage and (2) in contrast to the Caloosahatchee River, it experiences relatively natural flow periods (see Fig. 2 of annual discharge profiles), and its shoreline areas have been subjected to relatively minor anthropogenic modification. Further, although, much of the shoreline habitat of the Caloosahatchee estuary has largely been altered by urbanization, as evidenced by extensive shoreline modifications, the upper reaches and some downstream areas are composed of similar ecological communities, including saltmarsh and mangrove species (e.g. red mangrove Rhizophora mangle, black mangrove Avicennia germinans, saltmarsh cordgrass Spartina alterniflora and black needlerush Juncus roemerianus). Palmer et al. (2011) and Vinagre et al. (2011) conducted comparisons of community and food web structure of proximate estuaries in the Gulf of Mexico and Tagus Estuary, respectively, citing similar species composition among the 2 study systems. In this context, the Myakka estuary provides a reference by which a comparison of food web dynamics to the Caloosahatchee estuary can be made. 


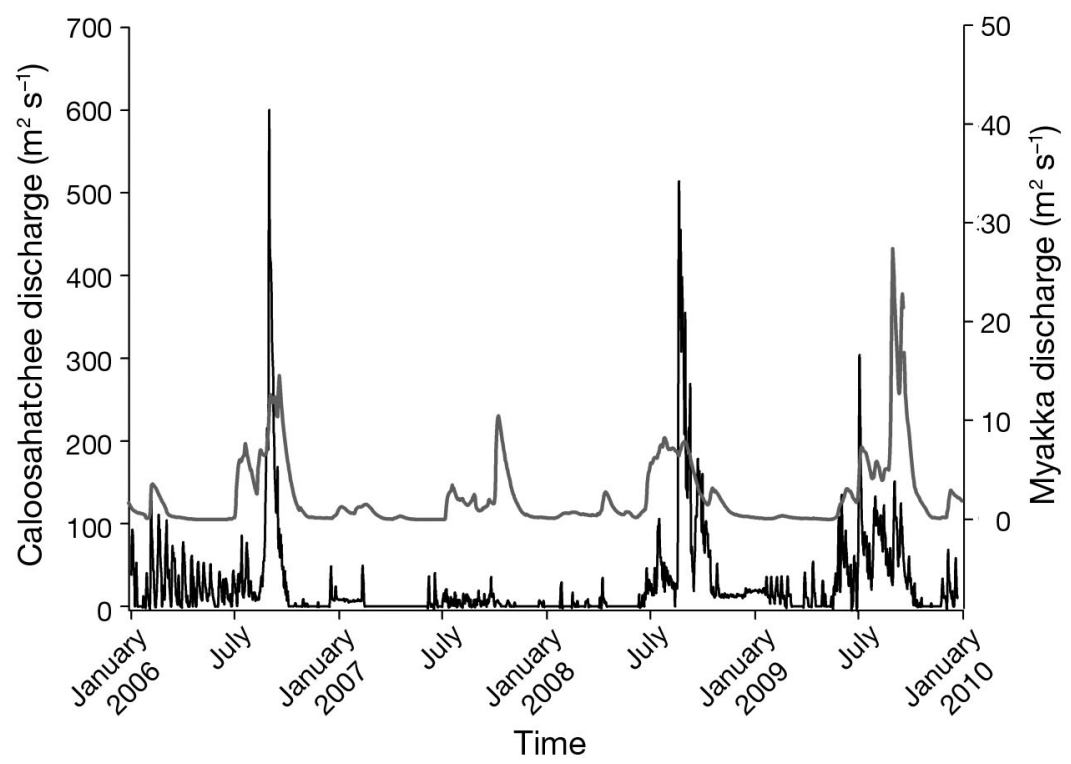

Fig. 2. Mean daily river discharge recorded in the Caloosahatchee (black line) and in the Myakka (gray line) from 2006 to 2010. River discharge data were obtained from the U.S. Geological Survey for the Myakka River near Sarasota (Station 02298830; http://water.usgs.gov/data) and from the South Florida Water Management District for the Caloosahatchee River at the Cape Coral Bridge (Station CCORAL; http://my.sfwmd.gov)

for crabs and disc width for stingrays (to the nearest $\mathrm{mm}$ ). White muscle tissue was excised from the dorsal area anterior to the first dorsal fin from all fishes and from the dorsal surface from stingrays. Oysters and crabs were dissected prior to drying and only muscle tissue was retained for stable isotope analyses. Muscle tissue samples were stored on ice in the field and then stored frozen upon return to the laboratory $\left(-20^{\circ} \mathrm{C}\right)$.

\section{Stable isotope analysis}

Muscle tissues were sub-sampled $(\sim 1.0 \mathrm{~g})$, freeze-dried for $48 \mathrm{~h}$, and homogenized in a SPEX CertiPrep 8000-D ball milling unit (SPEX CertiPrep). Lipids are depleted in ${ }^{13} \mathrm{C}$ relative to other major tissue components (i.e. proteins and carbohydrates, DeNiro \& Epstein 1977) and their presence in muscle tissue samples can negatively skew observed $\delta^{13} \mathrm{C}$ values

\section{Sample collection}

Samples were collected in 2008 following the dry (May and June) and wet (September and October) seasons that occur in the Myakka and Caloosahatchee estuaries. In an effort to sample a broad range of nekton species (see Table 1 for a complete list of species sampled), shallow water $(<10 \mathrm{~m})$ longlines $(800 \mathrm{~m})$, seines $(21.3 \mathrm{~m}$ with $3.2 \mathrm{~mm}$ stretch mesh, center bag), and trawls $(6.1 \mathrm{~m}$ with $38 \mathrm{~mm}$ stretch mesh, $3.2 \mathrm{~mm}$ stretch mesh liner) were used for all collections. Longlines were set for periods from 30 min to $2 \mathrm{~h}$, with most set for approximately $1.5 \mathrm{~h}$. The trawl was towed for 5 to $7 \mathrm{~min}$ at $0.6 \mathrm{~m} \mathrm{~s}^{-1}$, providing a tow length of $\sim 180 \mathrm{~m}$. Trawl width averaged $\sim 4 \mathrm{~m}$, providing an approximate area of $720 \mathrm{~m}^{2}$ sampled by a typical tow. The seine was deployed from a boat in a shallow arc parallel to shore and hauled directly along the shoreline. The 2 ends of the seine were pulled together, sampling an area of $\sim 68 \mathrm{~m}^{2}$.

During each sampling event, environmental parameters - including temperature $\left({ }^{\circ} \mathrm{C}\right)$, salinity (ppt) and dissolved oxygen $\left(\mathrm{mg} \mathrm{l}^{-1}\right)$ - were recorded from depths ranging from 0.5 to $2.5 \mathrm{~m}$ using an YSI water quality meter (see Table A1 in Appendix 1). Upon collection, all fishes and macro-invertebrates were measured; standard length for fishes, carapace width
(Post et al. 2007). To standardize $\delta^{13} \mathrm{C}$ values within and among species, lipids were removed from all samples prior to isotopic analysis using a modified method outlined by Bligh \& Dyer (1959): twice vortexing the pulverized tissue in $5 \mathrm{ml}$ of $2: 1$ chloroform: methanol solution for $24 \mathrm{~h}$ and decanting the solvent through filter paper to isolate the lipid-free sample.

Relative abundances of nitrogen $\left({ }^{15} \mathrm{~N} /{ }^{14} \mathrm{~N}\right)$ and carbon $\left({ }^{13} \mathrm{C} /{ }^{12} \mathrm{C}\right)$ isotopes were determined on $\sim 0.5 \mathrm{mg}$ sub-samples sealed in tin capsules on a Thermo Finnigan Delta ${ }^{\text {Plus }}$ mass-spectrometer (Thermo Finnigan) coupled with an elemental analyzer (Costech) at the Great Lakes Institute for Environmental Research. Relative abundances of sulfur $\left({ }^{34} \mathrm{~S} /{ }^{32} \mathrm{~S}\right)$ were determined on $\sim 2 \mathrm{mg}$ and $\sim 6 \mathrm{mg}$ sub-samples sealed in tin capsules on an Isochrom Continuous Flow IRMS (GV Instruments/Micromass) coupled with an elemental analyzer (Costech), at the Environmental Isotope Laboratory, University of Waterloo and by a Thermo-Electron Delta ${ }^{\text {Plus }}$ Advantage IRMS at the Colorado Plateau Stable Isotope Laboratory, Northern Arizona University, respectively.

Stable isotope results are expressed in standard delta notation $(\delta)$, defined as parts per thousand as follows: $\delta=\left[\left(\mathrm{R}_{\text {sample }} / \mathrm{R}_{\text {standard }}\right)-1\right] \times 10^{3}$ (Peterson \& Fry 1987), where $R$ is the ratio of heavy to light iso- 
Table 1. Trophic guilds ${ }^{\mathrm{a}}$ and resource use categories ${ }^{\mathrm{b}}$ based on dietary sources compiled from published literature, for consumer species sampled from the Caloosahatchee and Myakka estuaries

\begin{tabular}{|c|c|c|c|}
\hline Species & $\begin{array}{l}\text { Resource } \\
\text { use }\end{array}$ & Predominant prey items ${ }^{\mathrm{c}}$ & Reference \\
\hline \multicolumn{4}{|l|}{ Primary consumers } \\
\hline Crassostrea virginica, Eastern oyster & Pelagic & Plankton, Diatoms & Riera \& Richard (1996) \\
\hline Mugil cephalus, striped mullet & Benthic & Detritus, Microalgae & Platell et al. (2006) \\
\hline \multicolumn{4}{|l|}{ Secondary consumers } \\
\hline Callinectes sapidus, blue crab & Benthic & $\begin{array}{l}\text { Crustaceans, Mollusca, Detritus, } \\
\text { Algae }\end{array}$ & Laughlin (1982) \\
\hline Trinectes maculatus, hogchoker & Benthic & Annelids, Arthropods & Derrick \& Kennedy (1997) \\
\hline Eucinostomus harengulus, tidewater mojarra & Benthic & Crustaceans, Polychaetes, Mollusca & Ley et al. (1994) \\
\hline Eugerres plumieri, striped mojarra & Benthic & Crustaceans, Mollusca, Detritus & Austin \& Austin (1971) \\
\hline Lagodon rhomboides, pinfish & Benthic & $\begin{array}{l}\text { Mollusca, Crustaceans, } \\
\text { Polychaetes, Algae }\end{array}$ & Motta et al. (1995) \\
\hline Dasyatis sabina, Atlantic stingray & Benthic & $\begin{array}{l}\text { Crustaceans, Polychaetes, } \\
\text { Ophiuroidea }\end{array}$ & Cook (1994) \\
\hline Chaetodipterus faber, Atlantic spadefish & Pelagic & Hydrozoa, Anthozoa & Hayse (1990) \\
\hline Menticirrhus americanus, Southern kingfish & Benthic & Polychaetes, Molluscs, Penaeids & Woodland et al. (2011) \\
\hline \multicolumn{4}{|l|}{ Tertiary consumers } \\
\hline Ariopsis felis, hardhead catfish & Benthic & $\begin{array}{l}\text { Decapoda, Amphipoda, Small } \\
\text { teleosts }\end{array}$ & $\begin{array}{l}\text { Yáñez-Arancibia \& } \\
\text { Lara-Domínguez (1988) }\end{array}$ \\
\hline Lutjanus griseus, grey snapper & Benthic & $\begin{array}{l}\text { Teleosts (Engraulidae), Amphipoda, } \\
\text { Decapoda }\end{array}$ & Harrigan et al. (1989) \\
\hline Cynoscion arenarius, sand seatrout & Pelagic & Teleosts (Engraulidae), Penaeids & Sheridan et al. (1984) \\
\hline Bagre marinus, gafftopsail catfish & Benthic & $\begin{array}{l}\text { Brachyura, Stomatopoda, Small } \\
\text { teleosts }\end{array}$ & $\begin{array}{l}\text { Yáñez-Arancibia \& } \\
\text { Lara-Domínguez (1988) }\end{array}$ \\
\hline \multicolumn{4}{|l|}{ Piscivore } \\
\hline Carcharhinus leucas, bull shark & Benthic & $\begin{array}{l}\text { Teleosts (Ariidae), Elasmobranchs } \\
\text { (Dasyatidae) }\end{array}$ & $\begin{array}{l}\text { Cortés (1999), J.A. Olin } \\
\text { (unpub. data) }\end{array}$ \\
\hline \multicolumn{4}{|c|}{$\begin{array}{l}\text { a Trophic guilds defined as: primary consumer, diet composed largely of algae and detritus }(>70 \%) \text {; secondary consumer, } \\
\text { diet composed primarily of invertebrate species; tertiary consumer, diet composed of both fishes and invertebrates; pisci- } \\
\text { vore, diet composed primarily of fishes }(>80 \%)\end{array}$} \\
\hline \multicolumn{4}{|c|}{${ }^{\mathrm{b}}$ Resource use groups defined as dominant feeding type: benthic versus pelagic } \\
\hline \multicolumn{4}{|c|}{$\begin{array}{l}{ }^{\mathrm{C}} \text { Only the most frequently observed diet items are provided for each species. Predominant prey items for Carcharhinus } \\
\text { leucas presented here represent juvenile individuals }\end{array}$} \\
\hline
\end{tabular}

topes in the sample and standard. The standard reference material was atmospheric nitrogen for $\mathrm{N}_{2}$, Pee Dee Belemnite carbonate for $\mathrm{CO}_{2}$, and Canyon Diablo Troilite for $\mathrm{SO}_{4}$. The analytical precision based on the standard deviation of 2 standards (NIST 8414 and internal fish muscle lab standard; $\mathrm{n}=76$ ) for $\delta^{15} \mathrm{~N}$ were $0.10 \%$ and $0.21 \%$ and for $\delta^{13} \mathrm{C}$ were $0.06 \%$ and $0.09 \%$, respectively, and based on 3 sulfide standards (NBS-123, EIl-40 and EIL-43) for $\delta^{34} \mathrm{~S}$ was $0.3 \%$. Analytical accuracy based on the analysis of NIST standards [sucrose (NIST 8542); ammonium sulfate (NIST 8547)] and bovine liver and muscle ( $\mathrm{n}=$ 3 for each) performed with muscle tissue sample, was within $0.07 \%$ for $\delta^{15} \mathrm{~N}, 0.01 \%$ for $\delta^{13} \mathrm{C}$, and $0.5 \%$ for $\delta^{34} \mathrm{~S}$, of certified values.

\section{Data analysis}

To examine the effect of estuary, season and their interaction on isotope values of the food web, multivariate analysis of variance (MANOVA) was applied to stable isotope values of the Myakka (11 consumer species) and the Caloosahatchee (12 consumer species) food webs. Analysis of variance (ANOVA) was then used to specify significant differences found in MANOVA to $\delta^{13} \mathrm{C}, \delta^{15} \mathrm{~N}$, and $\delta^{34} \mathrm{~S}$. To examine which species were influenced by season (dry versus wet) within each estuary, Welch's paired $t$-tests were used on the $\delta^{15} \mathrm{~N}, \delta^{13} \mathrm{C}$ and $\delta^{34} \mathrm{~S}$ data of each species where sufficient data were available $(n \geq 3$; Table 2$)$. To further differentiate the food web response to season, all 
Table 2. Length and stable isotope values ( $\mathrm{n}=$ number of individuals sampled; mean $\pm \mathrm{SE}$ ) of species collected from the Myakka and Caloosahatchee estuaries following the 2008 dry and wet seasons. Length indicates standard length for fishes, disc width for stingrays and carapace width for crabs (all measured in $\mathrm{cm}$ )

\begin{tabular}{|c|c|c|c|c|c|c|c|c|c|c|}
\hline \multirow{2}{*}{$\begin{array}{l}\text { Species } \\
\text { Season }\end{array}$} & \multicolumn{5}{|c|}{ Myakka } & \multirow[b]{2}{*}{$\mathrm{n}$} & \multirow[b]{2}{*}{ Length $(\mathrm{cm})$} & \multicolumn{2}{|c|}{ Caloosahatchee } & \multirow[b]{2}{*}{$\delta^{34} \mathrm{~S}(\%)$} \\
\hline & & Length (cm) & $\delta^{13} \mathrm{C}(\%)$ & $\delta^{15} \mathrm{~N}(\%)$ & $\delta^{34} \mathrm{~S}(\%)$ & & & $\delta^{13} \mathrm{C}(\%)$ & $\delta^{15} \mathrm{~N}(\%)$ & \\
\hline \multicolumn{11}{|c|}{ Invertebrates } \\
\hline \multicolumn{11}{|c|}{ Crassostrea virginica, Eastern oyster } \\
\hline Dry & & & & & & 3 & & $-23.5 \pm 0.3$ & $4.9 \pm 0.2$ & $13.7 \pm 0.1$ \\
\hline Wet & & & & & & 3 & & $-23.0 \pm 0.6$ & $6.6 \pm 0.4$ & $11.1 \pm 0.5$ \\
\hline \multicolumn{11}{|c|}{ Callinectes sapidus, blue crab } \\
\hline Dry & 9 & $12.2 \pm 1.0$ & $-22.7 \pm 0.3$ & $8.5 \pm 0.6$ & $12.5 \pm 0.6$ & 3 & $19.0 \pm 1.7$ & $-20.6 \pm 0.3$ & $9.3 \pm 0.3$ & $14.0 \pm 0.8$ \\
\hline Wet & 6 & $15.3 \pm 0.3$ & $-18.6 \pm 0.5$ & $10.4 \pm 1.1$ & $9.9 \pm 1.0$ & 6 & $9.8 \pm 0.1$ & $-23.8 \pm 0.7$ & $10.7 \pm 0.4$ & $12.6 \pm 0.3$ \\
\hline \multicolumn{11}{|l|}{ Fishes } \\
\hline \multicolumn{11}{|c|}{ Mugil cephalus, striped mullet } \\
\hline Dry & 1 & 19.0 & -14.6 & 5.7 & 5.2 & 4 & $22.9 \pm 0.4$ & $-14.7 \pm 1.1$ & $7.8 \pm 0.4$ & $8.6 \pm 0.9$ \\
\hline Wet & 3 & $29.4 \pm 3.2$ & $-20.7 \pm 0.3$ & $8.4 \pm 0.3$ & $12.4 \pm 0.6$ & 6 & $19.1 \pm 7.5$ & $-22.7 \pm 1.8$ & $9.4 \pm 0.2$ & $9.7 \pm 1.1$ \\
\hline \multicolumn{11}{|c|}{ Trinectes maculatus, hogchoker } \\
\hline Dry & 3 & $7.9 \pm 0.7$ & $-21.0 \pm 1.9$ & $9.6 \pm 0.3$ & $7.2 \pm 0.6$ & & & & & \\
\hline Wet & 3 & $6.9 \pm 0.8$ & $-22.4 \pm 0.3$ & $11.0 \pm 0.5$ & $9.7 \pm 1.2$ & & & & & \\
\hline \multicolumn{11}{|c|}{ Eucinostomus harengulus, tidewater mojarra } \\
\hline Dry & & & & & & 5 & $10.4 \pm 0.4$ & $-15.2 \pm 0.5$ & $9.4 \pm 0.1$ & $8.8 \pm 1.3$ \\
\hline Wet & & & & & & 10 & $5.4 \pm 0.4$ & $-23.5 \pm 1.1$ & $10.5 \pm 0.4$ & $0.5 \pm 0.4$ \\
\hline \multicolumn{11}{|c|}{ Eugerres plumieri, striped mojarra } \\
\hline Dry & 3 & $9.5 \pm 0.8$ & $-22.8 \pm 0.5$ & $10.0 \pm 0.6$ & $10.6 \pm 0.5$ & 5 & $15.5 \pm 1.7$ & $-21.7 \pm 1.5$ & $10.9 \pm 0.4$ & $9.8 \pm 1.6$ \\
\hline Wet & 17 & $4.6 \pm 0.5$ & $-22.5 \pm 0.5$ & $9.0 \pm 0.1$ & $9.5 \pm 0.3$ & 10 & $12.7 \pm 1.3$ & $-20.5 \pm 1.8$ & $10.3 \pm 0.4$ & $8.6 \pm 1.5$ \\
\hline \multicolumn{11}{|c|}{ Lagodon rhomboides, pinfish } \\
\hline Dry & 10 & $9.6 \pm 0.4$ & $-21.8 \pm 0.5$ & $9.6 \pm 0.2$ & $13.5 \pm 0.3$ & 4 & $9.3 \pm 0.6$ & $-16.6 \pm 0.3$ & $9.7 \pm 0.6$ & $11.7 \pm 0.9$ \\
\hline Wet & 5 & $11.2 \pm 0.9$ & $-21.7 \pm 0.6$ & $10.0 \pm 0.2$ & $12.9 \pm 0.5$ & 5 & $12.0 \pm 1.9$ & $-19.7 \pm 0.8$ & $11.2 \pm 0.3$ & $12.3 \pm 0.8$ \\
\hline \multicolumn{11}{|c|}{ Dasyatis sabina, Atlantic stingray } \\
\hline Dry & & & & & & 3 & $23.5 \pm 1.7$ & $-14.9 \pm 0.2$ & $9.9 \pm 0.1$ & $8.2 \pm 1.8$ \\
\hline Wet & & & & & & 7 & $13.4 \pm 0.3$ & $-19.5 \pm 0.6$ & $12.1 \pm 0.4$ & $10.8 \pm 0.9$ \\
\hline \multicolumn{11}{|c|}{ Chaetodipterus faber, Atlantic spadefish } \\
\hline Dry & 4 & $10.5 \pm 2.8$ & $-21.3 \pm 0.6$ & $11.3 \pm 0.2$ & $11.8 \pm 0.5$ & 4 & $12.1 \pm 1.2$ & $-19.4 \pm 0.6$ & $11.6 \pm 0.4$ & $13.2 \pm 0.3$ \\
\hline Wet & 3 & $14.0 \pm 3.8$ & $-22.4 \pm 0.9$ & $11.1 \pm 0.2$ & $12.3 \pm 0.9$ & 8 & $17.9 \pm 0.9$ & $-20.0 \pm 0.6$ & $10.1 \pm 0.7$ & $10.7 \pm 1.0$ \\
\hline \multicolumn{11}{|c|}{ Menticirrhus americanus, Southern kingfish } \\
\hline Dry & 3 & $19.7 \pm 0.4$ & $-23.3 \pm 0.4$ & $11.0 \pm 0.4$ & $11.6 \pm 0.2$ & & & & & \\
\hline Wet & 5 & $22.6 \pm 0.2$ & $-21.8 \pm 0.2$ & $9.9 \pm 0.1$ & $12.1 \pm 0.1$ & & & & & \\
\hline \multicolumn{11}{|c|}{ Ariopsis felis, hardhead catfish } \\
\hline Dry & 10 & $29.7 \pm 1.5$ & $-21.4 \pm 0.5$ & $11.0 \pm 0.3$ & $12.7 \pm 0.6$ & 6 & $30.4 \pm 0.8$ & $-20.4 \pm 0.7$ & $11.3 \pm 0.4$ & $12.6 \pm 0.5$ \\
\hline Wet & 8 & $17.4 \pm 4.9$ & $-21.2 \pm 0.4$ & $10.7 \pm 0.3$ & $10.7 \pm 0.6$ & 24 & $23.5 \pm 1.8$ & $-21.2 \pm 0.4$ & $12.2 \pm 0.3$ & $12.6 \pm 0.5$ \\
\hline Lutjanus & rise & us, grey snap & per & & & & & & & \\
\hline Dry & & & & & & 5 & $16.2 \pm 1.3$ & $-14.5 \pm 0.7$ & $11.6 \pm 0.2$ & $10.9 \pm 0.5$ \\
\hline Wet & & & & & & 3 & $12.1 \pm 4.1$ & $-16.1 \pm 0.5$ & $11.8 \pm 0.2$ & $13.9 \pm 0.5$ \\
\hline Cynoscior & are & narius, sand & seatrout & & & & & & & \\
\hline Dry & 3 & $17.8 \pm 1.3$ & $-23.9 \pm 0.2$ & $12.4 \pm 0.1$ & $13.0 \pm 0.4$ & & & & & \\
\hline Wet & 5 & $27.6 \pm 4.4$ & $-21.7 \pm 0.2$ & $10.4 \pm 0.1$ & $12.0 \pm 0.1$ & & & & & \\
\hline Bagre ma & rinu & $S$, gafftopsail & catfish & & & & & & & \\
\hline Dry & 6 & $42.2 \pm 3.8$ & $-18.9 \pm 0.5$ & $12.1 \pm 0.1$ & $13.6 \pm 0.2$ & 6 & $40.6 \pm 1.8$ & $-19.4 \pm 0.6$ & $12.9 \pm 0.4$ & $12.9 \pm 0.5$ \\
\hline Wet & 11 & $36.4 \pm 3.2$ & $-19.4 \pm 0.3$ & $11.6 \pm 0.2$ & $12.2 \pm 0.4$ & 7 & $24.4 \pm 4.6$ & $-20.8 \pm 0.5$ & $12.8 \pm 0.5$ & $12.9 \pm 0.7$ \\
\hline Carcharh & inus & leucas, bull s & $\operatorname{hark}^{\mathrm{a}}$ & & & & & & & \\
\hline Dry & 3 & $102.5 \pm 3.0$ & $-17.8 \pm 0.4$ & $12.6 \pm 0.3$ & $11.0 \pm 0.6$ & 3 & $94.3 \pm 2.9$ & $-16.6 \pm 0.3$ & $12.6 \pm 0.2$ & $11.6 \pm 1.1$ \\
\hline Wet & 3 & $91.6 \pm 13.8$ & $-18.5 \pm 0.7$ & $12.7 \pm 0.2$ & $12.0 \pm 0.1$ & 3 & $102.1 \pm 12.6$ & $-17.4 \pm 0.5$ & $13.4 \pm 0.5$ & $13.3 \pm 1.0$ \\
\hline
\end{tabular}


species were (1) assigned to one of 4 groups termed 'trophic guilds' (see below) and (2) to one of 2 groups termed 'resource use categories' representing either pelagic or benthic feeders. All assignments were based on dietary data from the literature (see Table 1 for designation). Trophic guilds were defined as: (1) primary consumer, diet composed largely of algae and detritus $(>70 \%)$, (2) secondary consumer, diet composed primarily of invertebrate species, (3) tertiary consumer, diet composed of both fishes and invertebrates and (4) piscivore, diet composed primarily of fishes $(>80 \%)$. Resource use categories were defined by predominant feeding type based on dietary data as follows: (1) pelagic or (2) benthic (sensu Chanton \& Lewis 2002). To examine the influence of season, resource use and their interaction on the defined trophic guilds, a 2-factor ANOVA was applied to the $\delta^{15} \mathrm{~N}$, $\delta^{13} \mathrm{C}$ and $\delta^{34} \mathrm{~S}$ data of the secondary and tertiary consumers in the Myakka estuary, and the primary and secondary consumers in the Caloosahatchee estuary, as those trophic guilds included both pelagic and benthic feeders. Prior to all analyses an examination of probability plots and box plots showed data to be generally described by normally distributed errors. All analyses were conducted in R 2.13.0 (R Development Core Team 2011) with a criterion for significance of $p<0.05$ used for all statistical tests. values for the Caloosahatchee food web were more depleted in ${ }^{13} \mathrm{C}$, absolute range: -12.4 to -27.2 vs. -14.3 to -29.1 and enriched in ${ }^{15} \mathrm{~N}$ (4.5 to 14.1 vs. 6.1 to 14.4 ), by $\sim 2 \%$ in both instances, relative to the dry season stable isotope values (Fig. 3D,E). Results of ANOVA for $\delta^{34}$ S were significant for estuary $\times$ season interaction (Table 3), with the Myakka having higher mean $\delta^{34} \mathrm{~S}$ values relative to the Caloosahatchee food web (Fig. $3 \mathrm{C}, \mathrm{F}$ ). The range in $\delta^{34} \mathrm{~S}$ values in the Myakka food web, declined by $2 \%$ between dry and wet seasons (5.2 to 14.8 vs. 7.3 to 14.7, respectively) (Fig. $3 \mathrm{C}$ ). The range in $\delta^{34} \mathrm{~S}$ values observed between seasons in the Caloosahatchee food web were comparable (dry: -0.3 to 15.0 vs. wet: 1.4 to 16.4 ) (Fig. 3F).

In the Myakka food web, species exhibited a mixed response to the onset of the wet season, but overall significant shifts in isotope values were observed in fewer species than in the Caloosahatchee (Fig. 3A-C; Table A2 in Appendix 1). These differences were principally driven by tertiary consumers. No overall trend of depletion or enrichment was identified for ${ }^{13} \mathrm{C}$ (Fig. 3A) or ${ }^{15} \mathrm{~N}$ (Fig. 3B) between seasons. However significant depletion in ${ }^{34} \mathrm{~S}$ was identified in the tertiary consumers Ariopsis felis, Bagre marinus and Cynoscion arenarius in the wet season (Fig. 3C).

\section{RESULTS}

The results of the MANOVA revealed significant effects of estuary and of the estuary $x$ season interaction on the stable isotope values of the food web (Pillai Trace: $F_{1,257}=6.765$, $\mathrm{p}>0.0001 ; F_{1,257}=3.333, \mathrm{p}=0.020 ;$ Table 3). Results of ANOVA revealed that the estuary and estuary $\times$ season interaction differed in both their mean $\delta^{13} \mathrm{C}$ and $\delta^{15} \mathrm{~N}$ values, with the Myakka food web having lower $\delta^{13} \mathrm{C}$ and $\delta^{15} \mathrm{~N}$ values than the Caloosahatchee food web (Table 3, Fig. 3A,B,D,E). For the Myakka food web, a similar range in stable isotope values of $\delta^{13} \mathrm{C}$ and $\delta^{15} \mathrm{~N}$ were observed across all species in the dry and wet seasons: absolute range: -14.6 to -25.1 vs. -14.1 to -25.9 and 5.7 to 13.3 vs. 6.5 to 13.1 , respectively (Fig. 3A,B). Wet season stable isotope
Table 3. MANOVA and ANOVA results of stable isotopes values $\left(\delta^{13} \mathrm{C}, \delta^{15} \mathrm{~N}\right.$ and $\delta^{34} \mathrm{~S}$ ) among the Myakka and Caloosahatchee estuaries and between the 2008 wet and dry seasons (statistical significance in bold)

\begin{tabular}{|c|c|c|c|c|c|}
\hline \multicolumn{2}{|c|}{ MANOVA $\left(\delta^{13} \mathrm{C}, \delta^{15} \mathrm{~N}, \delta^{34} \mathrm{~S}\right)$} & df & Pillai & $F$ & $\mathrm{p}$ \\
\hline \multicolumn{2}{|l|}{ Estuary } & 1 & 0.074 & 6.765 & 0.000 \\
\hline \multicolumn{2}{|l|}{ Season } & 1 & 0.015 & 1.287 & 0.279 \\
\hline \multicolumn{2}{|l|}{ Estuary:season } & 1 & 0.038 & 3.333 & 0.020 \\
\hline \multicolumn{2}{|l|}{ Residuals } & 257 & & & \\
\hline ANOVA $\left(\delta^{13} \mathrm{C}\right)$ & $\mathrm{df}$ & SS & MS & $F$ & $\mathrm{p}$ \\
\hline Estuary & 1 & 85.930 & 85.930 & 10.126 & 0.002 \\
\hline Season & 1 & 19.730 & 19.731 & 2.325 & 0.129 \\
\hline Estuary:season & 1 & 38.360 & 38.362 & 4.520 & 0.034 \\
\hline Residuals & 257 & 2181.030 & 8.487 & & \\
\hline \multicolumn{6}{|l|}{$\operatorname{ANOVA}\left(\delta^{15} \mathrm{~N}\right)$} \\
\hline Estuary & 1 & 19.830 & 19.828 & 6.275 & 0.013 \\
\hline Season & 1 & 2.020 & 2.025 & 0.641 & 0.424 \\
\hline Estuary:season & 1 & 9.660 & 9.663 & 3.057 & 0.042 \\
\hline Residuals & 257 & 812.050 & 3.160 & & \\
\hline \multicolumn{6}{|l|}{ ANOVA $\left(\delta^{34} \mathrm{~S}\right)$} \\
\hline Estuary & 1 & 19.000 & 18.998 & 2.273 & 0.133 \\
\hline Season & 1 & 1.450 & 1.448 & 0.173 & 0.678 \\
\hline Estuary:season & 1 & 57.920 & 57.921 & 6.929 & 0.009 \\
\hline Residuals & 257 & 2148.430 & 8.360 & & \\
\hline
\end{tabular}




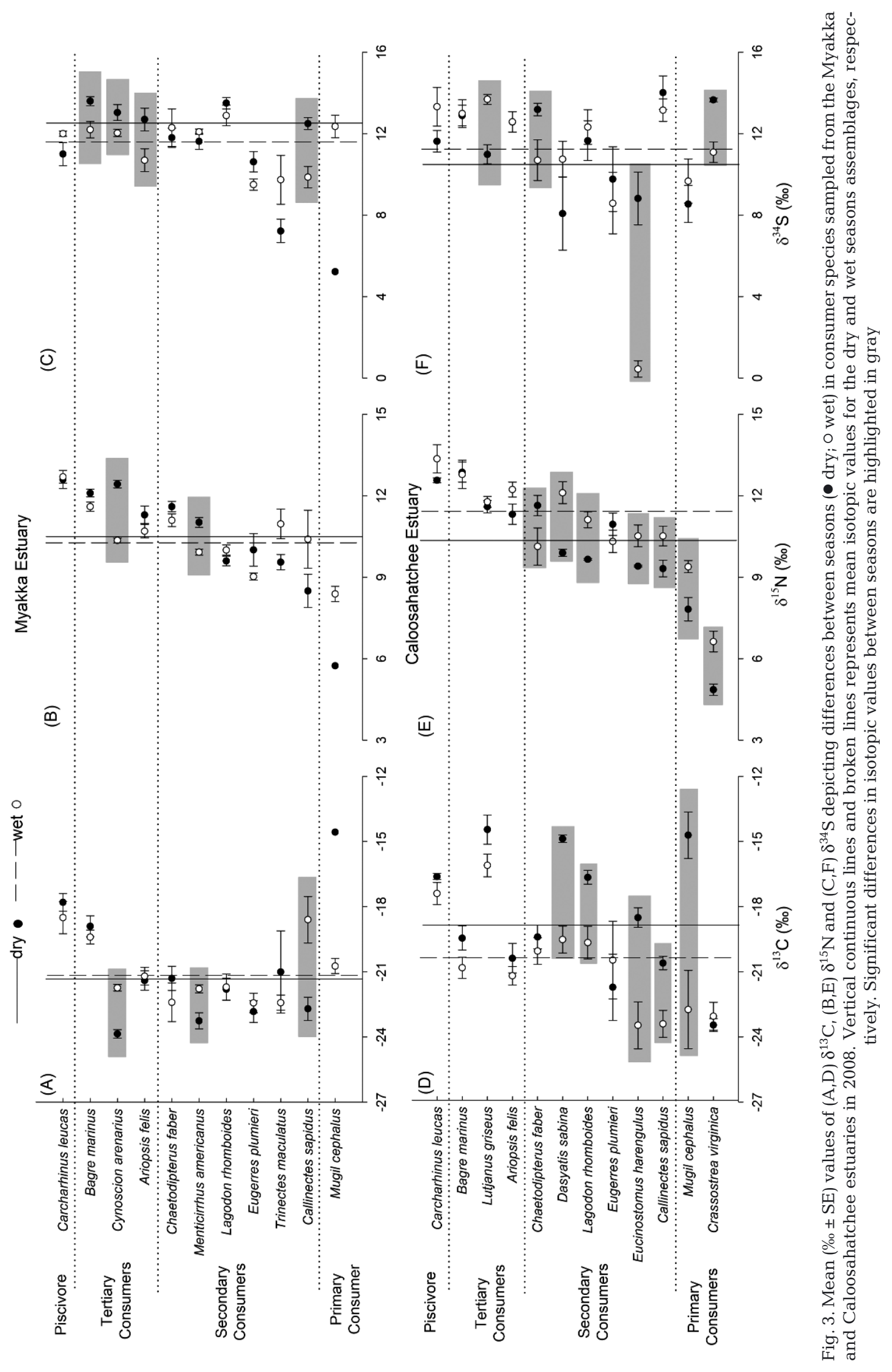


In contrast to the Myakka estuary, changes to the species level $\delta^{15} \mathrm{~N}$-, $\delta^{13} \mathrm{C}$ - and $\delta^{34} \mathrm{~S}$-season relationships in the Caloosahatchee estuary were predominantly driven by primary and secondary consumers (Table A2 in Appendix 1). Species whose $\delta^{13} \mathrm{C}$ values varied significantly between season were all depleted in ${ }^{13} \mathrm{C}$ following the wet season (Fig. 3D). For species that did not exhibit a significant shift in $\delta^{13} \mathrm{C}$, a declining trend in $\delta^{13} \mathrm{C}$ values with the wet season was observed, with the exception of Crassostrea virginica and Eugerres plumieri (Fig. 3D). The $\delta^{15} \mathrm{~N}$ values of the majority of primary and secondary consumers were significantly enriched in ${ }^{15} \mathrm{~N}$ following altered-high flow (i.e. Fig. 3E). The $\delta^{15} \mathrm{~N}$ values of the primary consumers C. virginica and Mugil cephalus significantly increased by approximately $2 \%$ and $1.5 \%$, respectively, between seasons (Fig. 3E). Unlike the Myakka food web, the $\delta^{34} \mathrm{~S}$ values of tertiary consumers of the Caloosahatchee food web did not show an overall change, although Lutjanus griseus exhibited enrichment in ${ }^{34} \mathrm{~S}$, whereas 3 primary and secondary consumers, C. virginica, Eucinostomus harengulus and Chaetodipterus faber, exhibited significant depletion in ${ }^{34} \mathrm{~S}$ following the wet season (Fig. 3F).
When considering the relationships between season (dry versus wet) and resource use (benthic vs. pelagic) of species assigned to particular trophic guilds in the Myakka food web, significant differences in $\delta^{34} \mathrm{~S}$ between seasons were identified for both secondary and tertiary consumers (Table 4 ). The $\delta^{15} \mathrm{~N}$ values varied significantly with resource use category in the secondary consumers, and with the interaction in tertiary consumers and the $\delta^{13} \mathrm{C}$ values varied significantly with resource use in the tertiary consumers (Table 4). Together the $\delta^{15} \mathrm{~N}$ and $\delta^{13} \mathrm{C}$ results identify that benthic and pelagic species derive their energy from different components of the food web. In contrast, in the Caloosahatchee food web, the $\delta^{13} \mathrm{C}$ and $\delta^{15} \mathrm{~N}$ values varied significantly with season, resource use category and in the case of $\delta^{13} \mathrm{C}$ the interaction for primary consumers (i.e. Crassostrea virginica and Mugil cephalus; Table 4), indicating that altered-high flow affects both pelagic and benthic components of the food web. For $\delta^{13} \mathrm{C}$, this was driven by the depletion observed in $M$. cephalus, whereas for $\delta^{15} \mathrm{~N}$, both primary consumers $M$. cephalus and C. virginica showed enriched values of $\sim 1.5 \%$ in the wet season. However, no season or resource use effects on $\delta^{13} \mathrm{C}$ or $\delta^{15} \mathrm{~N}$ were observed in secondary consumers. Statistically significant dif-

Table 4. Results of 2-way ANOVAs used to test the effect of (1) season (dry versus wet) and (2) resource use category within estuary (benthic versus pelagic) on $\delta^{13} \mathrm{C}, \delta^{15} \mathrm{~N}$, and $\delta^{34} \mathrm{~S}$ values of species within the designated trophic guilds (statistical significance in bold)

\begin{tabular}{|c|c|c|c|c|c|c|c|c|c|c|c|c|c|}
\hline & \multirow[t]{2}{*}{$\mathrm{df}$} & \multirow[b]{2}{*}{ SS } & \multicolumn{3}{|c|}{$\delta^{13} \mathrm{C}(\%)$} & \multicolumn{4}{|c|}{$-\delta^{15} \mathrm{~N}(\%)$} & \multicolumn{4}{|c|}{$\delta^{34} \mathrm{~S}(\%)$} \\
\hline & & & MS & $F$ & $\mathrm{p}$ & SS & MS & $F$ & $\mathrm{p}$ & SS & MS & $F$ & $\mathrm{p}$ \\
\hline \multicolumn{14}{|l|}{ MYAKKA } \\
\hline \multicolumn{14}{|l|}{ Secondary consumer } \\
\hline Season & 1 & 2.991 & 2.991 & 0.761 & 0.386 & 0.468 & 0.468 & 0.287 & 0.594 & 38.165 & 38.165 & 11.196 & 0.001 \\
\hline Resource use & 1 & 0.192 & 0.192 & 0.049 & 0.826 & 18.077 & 18.077 & 11.057 & 0.001 & 2.474 & 2.474 & 0.726 & 0.397 \\
\hline Season $\times$ resource use & 1 & 4.615 & 4.615 & 1.174 & 0.283 & 0.327 & 0.327 & 0.200 & 0.656 & 7.583 & 7.583 & 2.224 & 0.141 \\
\hline Error & 65 & 255.565 & 3.932 & & & 106.271 & 1.635 & & & 221.583 & 3.409 & & \\
\hline \multicolumn{14}{|l|}{ Tertiary consumer } \\
\hline Season & 1 & 1.138 & 1.138 & 0.448 & 0.507 & 2.77 & 2.770 & 3.550 & 0.066 & 14.587 & 14.587 & 7.061 & 0.011 \\
\hline Resource use & 1 & 43.605 & 43.605 & 17.158 & 0.000 & 0.761 & 0.762 & 0.976 & 0.328 & 0.907 & 0.907 & 0.439 & 0.511 \\
\hline Season $\times$ resource use & 1 & 6.355 & 6.355 & 2.501 & 0.121 & 5.791 & 5.791 & 7.424 & 0.009 & 0.008 & 0.008 & 0.004 & 0.949 \\
\hline Error & 45 & 114.361 & 2.541 & & & 35.104 & 0.780 & & & 92.961 & 2.066 & & \\
\hline \multicolumn{14}{|l|}{ CALOOSAHATCHEE } \\
\hline \multicolumn{14}{|l|}{ Primary consumer } \\
\hline Season & 1 & 75.478 & 75.478 & 8.039 & 0.015 & 14.489 & 14.489 & 35.825 & 0.000 & 1.380 & 1.380 & 0.357 & 0.561 \\
\hline Resource use & 1 & 65.588 & 65.588 & 6.986 & 0.021 & 30.319 & 30.319 & 74.965 & 0.000 & 36.192 & 36.192 & 9.373 & 0.010 \\
\hline Season $\times$ resource use & 1 & 65.534 & 65.534 & 6.980 & 0.022 & 0.039 & 0.039 & 0.098 & 0.760 & 12.620 & 12.620 & 3.268 & 0.096 \\
\hline Error & 12 & 112.670 & 9.389 & & & 4.853 & 0.404 & & & 46.337 & 3.861 & & \\
\hline \multicolumn{14}{|l|}{ Secondary consumer } \\
\hline Season & 1 & 10.651 & 10.651 & 0.703 & 0.405 & 1.194 & 1.194 & 0.652 & 0.423 & 27.475 & 27.475 & 1.642 & 0.206 \\
\hline Resource use & 1 & 0.000 & 0.000 & 0.000 & 0.987 & 0.063 & 0.063 & 0.034 & 0.854 & 75.010 & 75.010 & 4.481 & 0.039 \\
\hline Season $\times$ resource use & 1 & 7.918 & 7.918 & 0.523 & 0.473 & 4.856 & 4.856 & 2.650 & 0.109 & 51.259 & 51.259 & 3.062 & 0.086 \\
\hline Error & 56 & 848.330 & 15.149 & & & 102.618 & 1.832 & & & 920.590 & 16.738 & & \\
\hline
\end{tabular}


ferences in $\delta^{34} \mathrm{~S}$ were identified between benthic and pelagic species in both the primary and secondary consumer trophic guilds (Table 4).

\section{DISCUSSION}

Alterations that have been made to the Caloosahatchee River subject this system to extreme fluctuations in the volume and duration of freshwater inflow. Our seasonal comparison of trophic relationships of nekton assemblages in 2 subtropical tidal rivers that experience different seasonal flow dynamics, demonstrate patterns of isotopic change that are more evident in a flow-altered system relative to a more natural system. Although the study was only conducted over a $1 \mathrm{yr}$ period and is therefore not replicated, the clear changes in $\delta^{13} \mathrm{C}$ and $\delta^{15} \mathrm{~N}$ would suggest that anthropogenic altered flow does influence this estuarine community, and is consistent with other studies that ecological processes (i.e. species abundance and diversity) are modified in altered flow systems (Sheaves et al. 2007).

In the Myakka estuary, where the hydrology is more natural, there were no clear seasonal isotopic patterns, with the exception of more estuarine $\delta^{34} \mathrm{~S}$ values of tertiary consumers in the wet season. In the Caloosahatchee estuary, the results revealed a dichotomous response by estuarine species to seasonal flow dynamics. Specifically, a distinct shift to lower $\delta^{13} \mathrm{C}$ and higher $\delta^{15} \mathrm{~N}$ values was exhibited. This pattern was largely driven by primary and secondary consumers, i.e. was not evident among higher trophic level species but was observed in both pelagic and benthic components of this nekton community. The $\delta^{34} \mathrm{~S}$ values were less seasonally variable in the modified estuary and, in general, represented a more terrestrial/freshwater influenced value compared to the natural estuary - which may suggest that flow dynamics have a prolonged effect. Although the relative trophic structure, based on $\delta^{15} \mathrm{~N}$, was consistent across seasons and among estuaries, differences in the isotopic response of conspecifics to the wet season, specifically evident in $\delta^{13} \mathrm{C}$, support the assertion that altered freshwater flow dynamics affect nutrient sources available to consumers (Wai et al. 2008, Abrantes \& Sheaves 2010). Future work focused on continued monitoring of the seasonal dynamics in these estuarine systems is necessary to determine if this pattern is replicated over several years.

Consistent with observations of seasonal differences in basal productivity in hydrological-altered estuaries (Kaldy et al. 2005), nekton species in the
Caloosahatchee estuary exhibited significant changes in $\delta^{13} \mathrm{C}$ between seasons, a result not observed in conspecifics from the Myakka estuary. In general, carbon sourced from plants that use the $\mathrm{C}_{4}$ photosynthetic process, are enriched in ${ }^{13} \mathrm{C}\left(\delta^{13} \mathrm{C}\right.$ of $\mathrm{C}_{4}$ plants, -6 to $-19 \%$; Table 5) relative to carbon sourced from $\mathrm{C}_{3}$ plants and terrestrial sources $\left(\delta^{13} \mathrm{C}\right.$ of $\mathrm{C}_{3}$ plants, -24 to $-30 \%$; Table 5) (Moncreiff \& Sullivan 2001, Winemiller et al. 2007). Marine plankton $(-22 \%$, Chanton \& Lewis 1999) also tends to be more enriched than riverine plankton $(-28 \%$, Chanton \& Lewis 1999). The observed trends were consistent with our expectations of assimilation by the estuarine species of a ${ }^{13} \mathrm{C}$-depleted source following the compounded wet season. This trend was not evident in the Myakka estuary, as few species exhibited a shift in their $\delta^{13} \mathrm{C}$ values with season. In fact, the majority of species that did exhibit a significant shift became enriched in ${ }^{13} \mathrm{C}$ with the onset of the wet season, a result opposite to that expected and observed in the Caloosahatchee estuary. The significant $\delta^{13} \mathrm{C}$ variation in the Caloosahatchee estuary may be attributed to 2 effects: the increasing influence of terrestrial organic matter with high flow and/or the increasing influence of ${ }^{13} \mathrm{C}$-depleted dissolved inorganic carbon (DIC) sourcing phytoplankton in waters with decreasing salinity (Chanton \& Lewis 2002). Sampling these and other production sources over multiple annual seasonal cycles in these systems would be necessary to quantify the specific resource driving this trend.

The mean $\delta^{15} \mathrm{~N}$ value of the food web increased significantly following the wet season in the Caloosahatchee estuary. This increase was largely driven by the primary and secondary consumers. This trend was not apparent in the Myakka estuary, and the difference between systems is unlikely due to variation in body size (Olin et al. 2012). In addition, it is unlikely that prey resources shifted significantly with the wet season, as neither density nor species richness of consumers changed between seasons in the Caloosahatchee estuary (J. Olin unpubl. data). Rather, these differences likely reflected high nutrient loads to the Caloosahatchee River from considerable urban and agricultural runoff (Flaig \& Capece 1998), which has been observed in many other estuarine systems that have demonstrated a strong link between urban or agricultural lands and elevated $\delta^{15} \mathrm{~N}$ values in aquatic species (McClelland \& Valiela 1998, Winemiller et al. 2011). Although variable levels of enrichment in ${ }^{15} \mathrm{~N}$ were observed throughout the community the increase in $\delta^{15} \mathrm{~N}$ values between seasons is consistent with the decrease in values of 
Table 5. Isotopic values of potential organic matter sources compiled from published studies conducted in the Gulf of Mexico. Data are ranges of values from the referenced studies. Study areas: Apalachicola Bay, Florida (Chanton \& Lewis 1999, 2002, Wilson et al. 2009); Shark River Estuary, Florida (Fry \& Smith 2002); Mobile Bay, Alabama (Goecker et al. 2009); Horn Island, Mississippi (Moncreiff \& Sullivan 2001); Mad Island Marsh Estuary, Texas (Winemiller et al. 2007)

\begin{tabular}{|c|c|c|c|}
\hline Source & $\delta^{13} \mathrm{C}$ & $\delta^{34} \mathrm{~S}$ & Reference \\
\hline \multicolumn{4}{|l|}{ Detritus } \\
\hline $\begin{array}{l}\text { Detritus (e.g. mixed terrestrial } \\
\text { and macroalgae) }\end{array}$ & -26.8 to -26.6 & -0.4 to -4.9 & Goecker et al. (2009) \\
\hline Detritus (e.g. terrestrial) & -28.2 & 2.9 & Wilson et al. (2009) \\
\hline \multicolumn{4}{|l|}{ Plankton } \\
\hline Phytoplankton & -21.8 to -20.0 & 15.4 & Winemiller et al. (2007), Moncreiff \& Sullivan (2001) \\
\hline Zooplankton & -24.8 to -20.7 & 14.7 & Winemiller et al. (2007), Wilson et al. (2009) \\
\hline Plankton mixed (e.g. river) & -27.0 to -28.3 & -3.6 to 4.3 & Chanton \& Lewis (1999) \\
\hline Plankton mixed (e.g. marine) & -22.2 to -22.5 & 17.4 to 18.1 & Chanton \& Lewis (1999) \\
\hline \multicolumn{4}{|l|}{ Vegetation } \\
\hline Upland vegetation & -30.0 to -26.0 & -1.0 to 4.0 & Chanton \& Lewis (2002) \\
\hline $\mathrm{C}_{3}$ marsh vegetation (e.g. Juncus sp.) & -24.0 to -28.0 & -3.0 to 18.0 & Chanton \& Lewis (2002), Moncreiff \& Sullivan (2001) \\
\hline $\mathrm{C}_{4}$ vegetation (e.g. Spartina sp.) & -12.8 to -14.6 & -2.3 to 2.6 & Chanton \& Lewis (2002) \\
\hline Mangrove mixed (e.g. river) & -28.4 to -29.4 & 11.2 to 16.3 & Fry \& Smith (2002) \\
\hline \multicolumn{4}{|l|}{ Algae } \\
\hline $\begin{array}{l}\text { Macroalgae (e.g. Vallisneria, } \\
\text { Cladophora, Ulva sp.) }\end{array}$ & -16.8 to -22.4 & 2.3 to 18.2 & $\begin{array}{l}\text { Goecker et al. (2009), Winemiller et al. (2007), } \\
\text { Chanton \& Lewis (2002) }\end{array}$ \\
\hline Seagrass (e.g. Halodule wrightii) & -9.0 to -14.5 & -2.6 to 11.5 & Chanton \& Lewis (2002), Wilson et al. (2009) \\
\hline Epiphytic algae & -17.5 & 18.2 & Moncreiff \& Sullivan (2001) \\
\hline
\end{tabular}

$\delta^{13} \mathrm{C}$, providing support to a significant influence of the high flow on nutrient sources. However, as with the trend observed in $\delta^{13} \mathrm{C}$, measuring isotopic values of species and production sources in these communities in successive annual cycles would be necessary to confirm that these trends result from altered flow dynamics.

The absence of significant ${ }^{34} \mathrm{~S}$ depletion in the wet season across the Caloosahatchee consumers was unexpected given that the trend was observed in the Myakka estuary and in other estuarine systems (Chanton \& Lewis 2002). However, the majority of primary and secondary consumers sampled during the wet season in the Caloosahatchee estuary were depleted in ${ }^{34} \mathrm{~S}$ relative to those sampled during the dry season. Moreover 2 species that generally feed on pelagic resources, Crassostrea virginica and Chaetodipterus faber, did show significant depletion in ${ }^{34} \mathrm{~S}$ following high flow, suggestive of sulfate contributions from a freshwater source (Fry \& Chumchal 2011); a result similarly observed in a number of benthic consumers. These sulfur results suggest that high flow influence nutrient sources in the Caloosahatchee River and the lower observed $\delta^{34} \mathrm{~S}$ values relative to the Myakka River could indicate that altered flow may influence available nutrient sources for a longer period of time.
The magnitude of response of the upper trophic level consumers to altered flow in the Caloosahatchee estuary based on stable isotopes was less relative to the lower trophic level consumers. One explanation is that these upper trophic level consumers, which are generally more mobile, migrated out of the Caloosahatchee estuary during high flow and continued to feed on resources with similar isotope values. However, this seems unlikely given the species considered were sampled within the estuary during both collection periods and a number of studies have demonstrated that estuarine consumer species exhibit site fidelity and their tissues reflect the organic matter close to the areas they inhabit (Deegan \& Garritt 1997, Guest \& Connolly 2004). Rather, the absence of significant changes in the isotopic values in the upper trophic levels of the Caloosahatchee estuary may indicate that the duration of high freshwater flow was too short to elicit a shift in the isotope values of these larger bodied species. This delay could result from (1) slower muscle tissue turnover rates in higher trophic level and larger species (Logan \& Lutcavage 2010) and/or (2) a lag associated with movement of different isotopic values through the food web (e.g. Guelinckx et al. 2007, Jennings et al. 2008). This has consequences for using stable isotopes to assess trophic ecology of species that have 
isotope turnover times in sampled tissues that are longer than disturbance events (i.e. events that alter isotope values at the base of the food web). Sampling of high turnover tissues, for example blood plasma (Hobson \& Clark 1992) or the use of alternative chemical tracers such as fatty acids, could aid in clarifying this in higher trophic level species.

As the stable isotope values of muscle tissue reflect diet assimilated over a specific time period, minimal change in $\delta^{15} \mathrm{~N}$ and $\delta^{13} \mathrm{C}$ of the higher trophic level species residing in the Caloosahatchee estuary through both seasons indicated that the body composition of these animals reflect resources assimilated during both hydrologic regimes. It is important to note that if this disturbance event was of longer duration or occurred more frequently, for example as predicted by global climate change models (Pearlstine et al. 2010), then this alteration of the salinity gradient may have more serious consequences - particularly with respect to the physiological and dietary requirements of these species (e.g. maintaining osmotic balance; Nordlie 2006). For example, Jack et al. (2009) demonstrated an alteration to the diet of the red rock lobster Jasus edwardsii to a less preferable species as a consequence of prolonged low salinity. To advance our understanding of the species- and food web-level effects observed in this study, future studies should focus on determining seasonal trends in primary production and organic matter sources as well as monitoring trophic structure of food webs that experience varying flow management strategies.

\section{CONCLUSIONS}

Establishment of freshwater inflow criteria is becoming increasingly important (e.g. Arthington et al. 2006). Development of these criteria however is dependent on understanding the response of communities to altered freshwater flow regimes. Direct conclusions regarding the effect of altered freshwater flow dynamics on the nekton community of the Caloosahatchee estuary are difficult to state given the temporal period of this study. But the clear seasonal shifts in isotopic values between systems, predominantly driven by the lower trophic level species, would indicate that altered freshwater flow does affect available production resources to consumers. Shifts in resource use by primary and secondary consumers with flow are supported by previous studies in modified systems (Jack et al. 2009, McLeod et al. 2010), further corroborating our results. However, repetitive long-term sampling is required. Alteration to riverine flow indeed has implications for trophic interactions of estuarine species and, as presented here, the flow of energy to higher trophic levels through the food web. Whether this is advantageous (e.g. nutrients for production) or deleterious (e.g. mortality) for estuarine species requires further research. It is important to note that direct comparisons of these patterns to other estuarine systems warrants caution given differences in the magnitude of anthropogenic modification, the available production resources and species composition across even seemingly similar estuaries (Sheaves et al. 2007). Thus, the seasonal patterns identified in this study should be considered only in a broad sense. Regardless, changes to natural flow regimes that modify the duration and intensity of freshwater flow may hold significant consequences for the productivity of estuarine communities.

Acknowledgements. The authors thank P. Stevens, A. Timmers and the staff of the Florida Fish and Wildlife Conservation Commission's Charlotte Harbor Field Laboratory for their assistance with sample collection. We are grateful to W. Mark and R. Doucette for their assistance with sulfur-isotope processing. This research was conducted in accordance with an institutional animal use permit (University of Windsor: ACC AUPP \#07-13). This research was funded through University of Windsor scholarships to J.A.O. and National Science and Engineering Research Council of Canada Discovery grant funds to A.T.F.

\section{LITERATURE CITED}

Abrantes KG, Sheaves M (2010) Importance of freshwater flow in terrestrial-aquatic energetic connectivity in intermittently connected estuaries of tropical Australia. Mar Biol 157:2071-2086

Akin S, Winemiller KO, Gelwick FP (2003) Seasonal and spatial variation in fish and macrocrustracean assemblage structure in Mad Island Marsh Estuary, Texas. Estuar Coast Shelf Sci 57:269-282

Arthington AH, Bunn SE, Poff NL, Naiman RJ (2006) The challenges of providing environmental flow rules to sustain river ecosystems. Ecol Appl 16:1311-1318

Atwood TB, Wiegner TN, MacKenzie RA (2012) Effects of hydrological forcing on the structure of a tropical estuarine food web. Oikos 121:277-289

Austin H, Austin S (1971) The feeding habits of some juvenile marine fishes from the mangroves in western Puerto Rico. Caribb J Sci 11:171-178

Baptista J, Martinho F, Dolbeth M, Viegas I, Cabral H, Pardal M (2010) Effects of freshwater flow on the fish assemblage of the Mondego estuary (Portugal): comparison between drought and non-drought years. Mar Freshw Res 61:490-501

Bligh EG, Dyer WJ (1959) A rapid method of total lipid extraction and purification. Can J Biochem Physiol 37: 911-917 
Bunn SE, Arthington AH (2002) Basic principles and ecological consequences of altered flow regimes for aquatic biodiversity. Environ Manag 30:492-507

Chanton J, Lewis FG (1999) Plankton and dissolved inorganic carbon isotopic composition in a river-dominated estuary: Apalachicola Bay, Florida. Estuaries 22:575-583

Chanton J, Lewis FG (2002) Examination of coupling between primary and secondary production in a riverdominated estuary: Apalachicola Bay, Florida, USA. Limnol Oceanogr 47:683-697

Cook DA (1994). Temporal patterns of food habits of the Atlantic stingray Dasyatis sabina (Lesueur, 1824), from the Banana River Lagoon, Florida. MS thesis, Florida Institute of Technology, Melbourne, FL

> Cortés E (1999) Standardized diet compositions and trophic levels of sharks. ICES J Mar Sci 56:707-717

$>$ Deegan LA, Garritt RH (1997) Evidence for spatial variability in estuarine food webs. Mar Ecol Prog Ser 147:31-47

> DeNiro MJ, Epstein S (1977) Mechanism of carbon isotope fractionation associated with lipid synthesis. Science 197: 261-263

> Derrick PA, Kennedy VS (1997) Prey selection by the hogchoker, Trinectes maculatus (Pisces: Soleidae) along summer salinity gradients in Chesapeake Bay, USA. Mar Biol 129:699-711

Doering PH, Chamberlain RH (1998) Water quality in the Caloosahatchee Estuary, San Carlos Bay and Pine Island Sound. In: Proceedings of the Charlotte Harbor Public Conference and Technical Symposium, Technical Report no. 98-02, Charlotte Harbor National Estuary Program, Punta Gorda, FL, p 229-240

> Drinkwater KF, Frank KT (1994) Effect of river regulation and diversion on marine fish and invertebrates. Aquat Conserv 4:135-151

$>$ Dynesius M, Nilsson C (1994) Fragmentation and flow regulation of river systems in the northern third of the world. Science 266:753-762

Edeline E, Dufour S, Elie P (2005) Role of glass eel salinity preference in the control of habitat selection and growth plasticity in Anguilla anguilla. Mar Ecol Prog Ser 304: 191-199

Flaig EG, Capece J (1998) Water use and runoff in the Caloosahatchee watershed. In: Proceedings of the Charlotte Harbor Public Conference and Technical Symposium, Technical Report no. 98-02, Charlotte Harbor National Estuary Program, Punta Gorda, FL, p 73-80

- Fry B, Chumchal MM (2011) Sulfur stable isotope indicators of residency in estuarine fish. Limnol Oceanogr 56: 1563-1576

Fry B, Smith TJ (2002) Stable isotope studies of red mangroves and filter feeders from the Shark River estuary, Florida. Bull Mar Sci 70:871-890

> Gelwick FP, Akin S, Arrington DA, Winemiller KO (2001) Fish assemblage structure in relation to environmental variation in a Texas Gulf coast wetland. Estuaries 24: 285-296

Goecker ME, Valentine JF, Sklenar SA, Chaplin GI (2009) Influence from hydrological modification on energy and nutrient transference in a deltaic food web. Estuaries Coasts 32:173-187

Greenwood MFD, Stevens PW, Matheson RE (2006) Effects of the 2004 Hurricanes on the fish assemblages in two proximate southwest Florida estuaries: changes in the context of inter-annual variability. Estuaries Coasts 29: 985-996
Greenwood MFD, Matheson RE, McMichael RH, MacDonald TC (2007) Community structure of shoreline nekton in the estuarine portion of the Alafia River, Florida: differences along a salinity gradient and inflow-related changes. Estuar Coast Shelf Sci 74:223-238

Guelinckx J, Maes J, Van Den Driessche P, Geysen B, Dehairs F, Ollevier F (2007) Changes in $\delta^{13} \mathrm{C}$ and $\delta^{15} \mathrm{~N}$ in different tissues of juvenile sand goby Pomatoschistus minutus: a laboratory diet-switch experiment. Mar Ecol Prog Ser 341:205-215

Guest MA, Connolly RM (2004) Fine-scale movement and assimilation of carbon in saltmarsh and mangrove habitat by resident animals. Aquat Ecol 38:599-609

Harrigan P, Zieman JC, Macko SA (1989) The base of nutritional support for the gray snapper (Lutjanus griseus): an evaluation based on a combined stomach content and stable isotope analysis. Bull Mar Sci 44:65-77

Hayse JW (1990) Feeding habits, age, growth, and reproduction of Atlantic spadefish Chaetodipterus faber (Pisces: Ephippidae) in South Carolina. Fish Bull 88:67-83

Hobson KA, Clark RG (1992) Assessing avian diets using stable isotopes I: turnover of ${ }^{13} \mathrm{C}$ in tissues. Condor 94 : 181-188

Hsieh HL, Chen CP, Chen YG, Yan HH (2002) Diversity of benthic organic matter flows through polychaetes and crabs in a mangrove estuary: $\delta^{13} \mathrm{C}$ and $\delta^{34} \mathrm{~S}$. Mar Ecol Prog Ser 227:145-155

> Jack L, Wing SR, McLeod RJ (2009) Prey base shifts in red rock lobster Jasus edwardsii in response to habitat conversion in Fiordland marine reserves: implications for effective spatial management. Mar Ecol Prog Ser 381: 213-222

> Jennings S, Maxwell TAD, Schratzberger M, Milligan SP (2008) Body-size dependent temporal variation in nitrogen stable isotope ratios in food webs. Mar Ecol Prog Ser 370:199-206

> Kaldy JE, Cifuentes LA, Brock D (2005) Using stable isotope analyses to assess carbon dynamics in a shallow subtropical estuary. Estuaries 28:86-95

> Kelly MH, Gore JA (2008) Florida river flow patterns and the Atlantic multidecadal oscillation. Riv Res Appl 24: 598-616

> Kingsford RT (2011) Conservation management of rivers and wetlands under climate change-a synthesis. Mar Freshw Res 62:217-222

Laughlin RA (1982) Feeding habits of the blue crab, Callinectes sapidus (Rathbun), in the Apalachicola Estuary, Florida. Bull Mar Sci 32:807-822

Ley JA, Montague CL, McIvor CC (1994) Food habits of mangrove fishes: a comparison along estuarine gradients in northeastern Florida Bay. Bull Mar Sci 54:881-899

Logan JM, Lutcavage ME (2010) Stable isotope dynamics in elasmobranch fishes. Hydrobiologia 644:231-244

Lotze HK, Lenihan HS, Bourque BJ, Bradbury RH and others (2006) Depletion, degradation, and recovery potential of estuaries and coastal seas. Science 312:1806-1809

Mallin MA, Paerl HW, Rudek J, Bates PW (1993) Regulation of primary production by watershed rainfall and river flow. Mar Ecol Prog Ser 93:199-203

> McClelland JW, Valiela I (1998) Linking nitrogen in estuarine producers to land-derived sources. Limnol Oceanogr 43:577-585

> McLeod RJ, Wing SR (2008) Influence of altered salinity regime on the population structure of two infaunal bivalve species. Estuar Coast Shelf Sci 78:529-540 
McLeod RJ, Wing SR, Davis JP (2010) Habitat conversion and species loss alters the composition of carbon sources to benthic communities. Mar Ecol Prog Ser 411:127-136

Moncreiff CA, Sullivan MJ (2001) Trophic importance of epiphytic algae in subtropical seagrass beds: evidence from multiple stable isotope analyses. Mar Ecol Prog Ser 215:93-106

- Montagna PA, Alber M, Doering P, Connor MS (2002) Freshwater inflow: science, policy, management. Estuaries 25: 1243-1245

Motta PJ, Clifton KB, Hernandez P, Eggold BT, Giordano SD, Wilcox R (1995) Feeding relationships among nine species of seagrass fishes of Tampa Bay, Florida. Bull Mar Sci 56:185-200

> Nilsson C, Reidy CA, Dynesius M, Revenga C (2005) Fragmentation and flow regulation of the world's large river systems. Science 308:405-408

- Nordlie FG (2006) Physiochemical environments and tolerances of cyprinodontoid fishes found in estuaries and salt marshes of eastern North America. Rev Fish Biol Fish 16: 51-106

> Olin JA, Hussey NE, Fritts M, Heupel MR, Simpfendorfer CA, Poulakis GR, Fisk AT (2011) Maternal meddling in neonatal sharks: implication for interpreting stable isotopes in young animals. Rapid Commun Mass Spectrom 25:1008-1016

> Olin JA, MacNeil MA, Rush SA, Fisk AT (2012) Isotopic ratios reveal mixed seasonal variation among fishes from subtropical estuarine systems. Estuaries Coasts 35: 811-820

Paerl HW, Rossignol KL, Hall SN, Peierls BL, Wetz MS (2010) Phytoplankton community indicators of short- and long-term ecological change in the anthropogenically and climatically impacted Neuse River Estuary, North Carolina, USA. Estuaries Coasts 33:485-497

- Palmer TA, Montagna PA, Pollack JB, Kalke RD, DeYoe HR (2011) The role of freshwater inflow in lagoons, rivers, and bays. Hydrobiologia 667:49-67

Pearlstine LG, Pearlstine EV, Aumen NG (2010) A review of the ecological consequence and management implications of climate change for the Everglades. J N Am Benthol Soc 29:1510-1526

$>$ Peterson BJ, Fry B (1987) Stable isotopes in ecosystem studies. Annu Rev Ecol Syst 18:293-320

- Platell ME, Orr PA, Potter IC (2006) Inter- and intra-specific partitioning of food resources by six large and abundant fish species in a seasonally-open estuary. J Fish Biol 69: 243-262

Post DM, Layman CA, Arrington DA, Takimoto G, Quattrochi J, Montaña CG (2007) Getting to the fat of the matter: models, methods and assumptions for dealing with lipids in stable isotope analyses. Oecologia 152:179-189

> Pringle CM (2001) Hydrologic connectivity and the management of biological reserves: A global perspective. Ecol Appl 11:981-998

R Development Core Team (2011) R: A language and environment for statistical computing. R Foundation for Statistical Computing, Vienna

Rakocinski CF, Baltz DM, Fleeger JW (1992) Correspondence between environmental gradients and the com- munity structure of marsh-edge fishes in a Louisiana estuary. Mar Ecol Prog Ser 80:135-148

- Rehage JS, Trexler JC (2006) Assessing the net effect of anthropogenic disturbance on aquatic communities in wetlands: community structure relative to distance from canals. Hydrobiologia 569:359-373

> Riera P, Richard P (1996) Isotopic determination of food sources of Crassostrea gigas along a trophic gradient in the estuarine bay of Marennes-Oléron. Estuar Coast Shelf Sci 42:347-360

Rush SA, Olin JA, Fisk AT, Woodrey MS, Cooper RJ (2010) Trophic relationships of a marsh bird differ between Gulf coast estuaries. Estuaries Coasts 33:963-970

- Serrano X, Grosell M, Serafy JE (2010) Salinity selection and preference of the grey snapper Lutjanus griseus: field and laboratory observations. J Fish Biol 76:1592-1608

> Sheaves M, Johnston R, Molony B, Shepard G (2007) The effect of impoundments on the structure and function of fish fauna in a highly regulated dry tropics estuary. Estuaries Coasts 30:507-517

Sheridan PF, Trimm DL, Baker BM (1984) Reproduction and food-habits of 7 species of Northern Gulf of Mexico fishes. Contrib Mar Sci 27:175-203

Sklar FH, Browder JA (1998) Coastal environmental impacts brought about by alterations to freshwater flow in the Gulf of Mexico. Environ Manag 22:547-562

> Vinagre C, Salgado J, Cabral HN, Costa MJ (2011) Food web structure and habitat connectivity in fish estuarine nurseries - impact of river flow. Estuaries Coasts 34: 663-674

Wai TC, Ng JSS, Leung KMY, Dudgeon D, Williams GA (2008) The source and fate of organic matter and the significance of detrital pathways in a tropical coastal ecosystem. Limnol Oceanogr 53:1479-1492

> Wainright SC, Weinstein MP, Able KW, Currin CA (2000) Relative importance of benthic microalgae, phytoplankton and the detritus of smooth cordgrass Spartina alterniflora and the common reed Phragmites australis to brackish-marsh food webs. Mar Ecol Prog Ser 200:77-91

> Wilson RM, Chanton J, Lewis G, Nowacek D (2009) Combining organic matter source and relative trophic position determinations to explore trophic structure. Estuaries Coasts 32:999-1010

Winemiller KO, Akin S, Zeug SC (2007) Production sources and food web structure of a temperate tidal estuary: integration of dietary and stable isotope data. Mar Ecol Prog Ser 343:63-76

- Winemiller KO, Hoeinghaus DJ, Pease AA, Esselman PC and others (2011) Stable isotope analysis reveals food web structure and watershed impacts along the fluvial gradient of a Mesoamerican river. River Res Appl 27: 791-803

> Woodland RJ, Secor DH, Wedge ME (2011) Trophic resource overlap between small elasmobranchs and sympatric teleosts in mid-Atlantic Bight nearshore habitats. Estuaries Coasts 34:391-404

Yáñez-Arancibia A, Lara-Domínguez AL (1988) Ecology of three sea catfishes (Ariidae) in a tropical coastal ecosystem-Southern Gulf of Mexico. Mar Ecol Prog Ser 49: 215-230 


\section{Appendix 1}

Table A1. Environmental parameters (salinity, temperature and dissolved oxygen [DO]) measured from each sampling event in the Caloosahatchee and Myakka estuaries following the dry (May and June) and wet (August and September) seasons of 2008. Data are mean $\pm \mathrm{SE}$

\begin{tabular}{|lrrrr|}
\hline & \multicolumn{2}{c|}{ Caloosahatchee } & \multicolumn{3}{c|}{ Myakka } & Dry $(\mathrm{n}=29)$ & Wet $(\mathrm{n}=30)$ \\
\cline { 2 - 5 } & Dry $(\mathrm{n}=23)$ & Wet $(\mathrm{n}=36)$ & $24.1 \pm 1.2$ & $10.0 \pm 1.6$ \\
Salinity (ppt) & $27.5 \pm 7.4$ & $3.9 \pm 2.9$ & $29.0 \pm 0.3$ & $28.4 \pm 0.2$ \\
Temperature $\left({ }^{\circ} \mathrm{C}\right)$ & $28.9 \pm 1.5$ & $28.6 \pm 1.5$ & $5.7 \pm 0.1$ & $6.4 \pm 0.2$ \\
DO $\left(\mathrm{mg} \mathrm{l}^{-1}\right)$ & $6.3 \pm 0.9$ & $5.33 \pm 0.2$ & & \\
\hline
\end{tabular}

Table A2. Welch's paired $t$-test results ( $t$-value and p-value) comparing $\delta^{13} \mathrm{C}, \delta^{15} \mathrm{~N}$ and $\delta^{34} \mathrm{~S}$ values among consumer species sampled following the dry and wet seasons in the Caloosahatchee and Myakka estuaries (statistical significance in bold)

\begin{tabular}{|c|c|c|c|c|c|c|c|c|c|c|c|c|}
\hline Species & \multicolumn{2}{|c|}{$\delta^{13} \mathrm{C}(\%)$} & \multicolumn{2}{|c|}{$\begin{array}{c}\text { Caloosahatchee } \\
\delta^{15} \mathrm{~N}(\%)\end{array}$} & \multicolumn{2}{|c|}{$\delta^{34} \mathrm{~S}(\%)$} & \multicolumn{2}{|c|}{$\delta^{13} \mathrm{C}(\%)$} & \multicolumn{2}{|c|}{$\begin{array}{l}\text { Myakka } \\
\delta^{15} \mathrm{~N}(\%)\end{array}$} & \multicolumn{2}{|c|}{$\delta^{34} \mathrm{~S}(\%)$} \\
\hline \multicolumn{13}{|l|}{ Primary consumers } \\
\hline $\begin{array}{l}\text { Crassostrea virginica, } \\
\text { Eastern oyster }\end{array}$ & 0.574 & 0.609 & 4.078 & 0.024 & -4.985 & 0.034 & & & & & & \\
\hline Mugil cephalus, striped mullet & -3.849 & 0.005 & 3.223 & 0.026 & 0.799 & 0.447 & & & & & & \\
\hline \multicolumn{13}{|l|}{ Secondary consumers } \\
\hline Callinectes sapidus, blue crab & -4.033 & 0.005 & 2.509 & 0.043 & -0.865 & 0.437 & 3.426 & 0.010 & 1.552 & 0.158 & -4.458 & 0.002 \\
\hline Trinectes maculatus, hogchoker & -0.369 & 0.739 & 0.118 & 0.915 & 1.904 & 0.161 & & & & & & \\
\hline $\begin{array}{l}\text { Eucinostomus harengulus, } \\
\text { tidewater mojarra }\end{array}$ & 3.774 & 0.002 & -3.611 & 0.003 & 6.152 & 0.000 & & & & & & \\
\hline $\begin{array}{l}\text { Eugerres plumieri, } \\
\text { striped mojarra }\end{array}$ & 0.531 & 0.605 & -1.085 & 0.301 & -0.541 & 0.599 & 0.162 & 0.873 & 0.432 & 0.682 & -0.523 & 0.610 \\
\hline Lagodon rhomboides, pinfish & -3.417 & 0.029 & 4.419 & 0.021 & 0.513 & 0.626 & 0.159 & 0.877 & 1.734 & 0.112 & -1.103 & 0.309 \\
\hline Dasyatis sabina, Atlantic stingray & -7.180 & 0.000 & 5.229 & 0.001 & 1.311 & 0.346 & & & & & & \\
\hline $\begin{array}{l}\text { Chaetodipterus faber, } \\
\text { Atlantic spadefish }\end{array}$ & -1.367 & 0.259 & 2.521 & 0.040 & 3.245 & 0.007 & -1.073 & $0.352-$ & -0.506 & 0.637 & 0.511 & 0.645 \\
\hline $\begin{array}{l}\text { Menticirrhus americanus, } \\
\text { Southern kingfish }\end{array}$ & 3.552 & 0.037 & -5.039 & 0.010 & 1.106 & 0.370 & & & & & & \\
\hline \multicolumn{13}{|l|}{ Tertiary consumers } \\
\hline Ariopsis felis, hardhead catfish & -1.002 & 0.341 & 1.953 & 0.076 & 0.026 & 0.979 & 0.379 & 0.710 & -0.650 & 0.525 & -2.566 & 0.021 \\
\hline Lutjanus griseus, grey snapper & -1.959 & 0.098 & 0.564 & 0.594 & 5.138 & 0.002 & & & & & & \\
\hline $\begin{array}{l}\text { Cynoscion arenarius, } \\
\text { sand seatrout }\end{array}$ & 3.267 & 0.006 & -2.596 & 0.043 & -3.229 & 0.038 & & & & & & \\
\hline Bagre marinus, gafftopsail catfish & -1.866 & 0.090 & -0.121 & 0.906 & 0.115 & 0.911 & -0.852 & 0.415 & -1.957 & 0.081 & -3.066 & 0.008 \\
\hline Piscivore & & & & & & & & & & & & \\
\hline Carcharhinus leucas, bull shark & -1.367 & 0.259 & 2.001 & 0.149 & 1.685 & 0.181 & -0.869 & 0.446 & 0.299 & 0.782 & 1.561 & 0.246 \\
\hline
\end{tabular}

Editorial responsibility: Kenneth Heck Jr., Dauphin Island, Alabama, USA
Submitted: September 5, 2012, Accepted: May 3, 2013 Proofs received from author(s): July 13, 2013 